\title{
Geophysical techniques to evaluate environmental impacts by tannery industry
}

Lau, A. M. P., LPH-UFPR; Ferreira, F. J. F., LPGA-UFPR; Stevanato, R., LPGA-UFPR; Rosa Filho, E. F. da; LPH-UFPR; Zuqui, A. R., LPH-UFPR

Copyright 2018, SBGf - Sociedade Brasileira de Geofísica

Este texto foi preparado para a apresentação no VIII Simpósio Brasileiro de Geofísica, Salinópolis, 18 a 20 de setembro de 2018. Seu conteúdo foi revisado pelo Comitê Técnico do VIII SimBGf, mas não necessariamente representa a opinião da SBGf ou de seus associados. É proibida a reprodução total ou parcial deste material para propósitos comerciais sem prévia autorização da SBGf.

\begin{abstract}
Bovine leather tanning produces a large amount of waste, mainly liquids that can present elevated values of total dissolved solids, $\mathrm{Cr}, \mathrm{Fe}$, among others. Due to the high organic load, the oxygen of the rivers can be depleted. The study scope was to investigate a tannery industry shallow subsurface using electrical resistivity and induced polarization geophysical methods. The refereed industry operates since 1993 and is located in Portão, State of Rio Grande do Sul, southern Brazil. This study aimed the geophysical mapping of the contaminant plume and also to determine the groundwater flow direction. Generally, the chromium occurs in its trivalent state in minerals, and can be oxidized to the hexavalent state (carcinogenic) in alkaline environments. Due the presence of acids and salts in tanning wastewater the amount of total dissolved solids increases substantially in soil and groundwater, turning them more conductive. Twelve survey lines were set using dipole-dipole array to acquire the geoelectric data. The results are displayed in depth models, allowing to characterize the plume by its low resistivity values $(<60$ Ohm.m), most of them corresponding with low chargeability values $(<3 \mathrm{mV} / \mathrm{V})$. Contrasting with the residual soil and sandstone that are not contaminated. The models allowed to estimate the plume dimension and determinate its preferential flow direction, that matches the terrain topography.
\end{abstract}

\section{Introduction}

Chromium is the main chemical element used in the tannery industry being released to the environment, may causing problem to the public health as they have toxic effects even when present in low concentration. The main objective of the study is to investigate a tannery industry area subsurface using geophysical methods. The refereed industry operates since 1993. Research about the proper disposal of tanning wastewater is recent, as there are a few previous studies. Telford et al. (1990), Kearey et al. (2002), Milsom (2003), Reynolds (2003), demonstrate the main theoretical foundation of the methods. Electrical resistivity and induced polarization were the methods applied at this study, aiming to detect and outline the plume, determine its flow direction and ascertain the efficiency of the indirect methods. Due the presence of acids and salts in tanning wastewater the amount of total dissolved solids increases substantially in soil and groundwater, turning them more conductive. Therefore, it justifies the use of geophysical methods in this environmental context. In this context, researches of Cunha \& Shiraiwa (2011); Nunes \& Luiz (2006); Fachin et al. (2006); and Migliorini et al. (2006) are of major importance to understand this type of environment more prone to contamination.

\section{Geology and study area location}

At the study area region there are two different lithologies, the Botucatu Formation composed of fluvial-aeolian sandstones and the Serra Geral Formation withbasaltic and intermediate volcanic rocks (CPRM, 2006). The first formation constitutes the Guarani Aquifer System. Quaternary deposits are present in the region, correlated to the erosion of the cited rocks. According to CPRM (2005), those deposits are formed by residual soil gravity transported sediment (colluvium), alluvial fans and braided channels sediment. The geological map of the region is presented in figure 1 , characterised by sandy alluvial deposits overlaying the Botucatu Formation.

\section{Geoelectric methods}

Electrical resistivity (RES) and induced polarization (IP) are used frequently in hydrogeology and in environmental contaminated sites. The data were acquired using Iris Instruments, composed of the multichannel receiver (ELREC PRO), the transmitter VIP $3000 \mathrm{~W}$ and nonpolarizable electrodes. The method applied was the dipole-dipole array $(A B=M N=10 m)$, examining six levels of depth. The length of all SN survey lines is $140 \mathrm{~m}$, while the EW ranges from 70 to $160 \mathrm{~m}$. The figure 2 shows the survey line array, their names, the whole study area and the tannery location. ER and IP response to the subsurface geological setting, according to their propriety (Telford el al., 1990). Contaminants may change the electrical response of soils and groundwater. Therefore, the methods applied in this study can detect areas affected by contaminants. The resistivity and chargeability data are presented using depth models. The geoelectrical surveys use pairs of current-potential electrodes, through which apparent resistivity and chargeability measures are acquired (time domain). The main factors influencing variations in electrical resistivity of materials are the mineralogical composition, the porosity, the fluids composition, the total dissolved solids (TDS) and the temperature. The apparent resistivity and demand ability data, as well as the processed (inverted) data, are presented in profiles and 2D maps. 


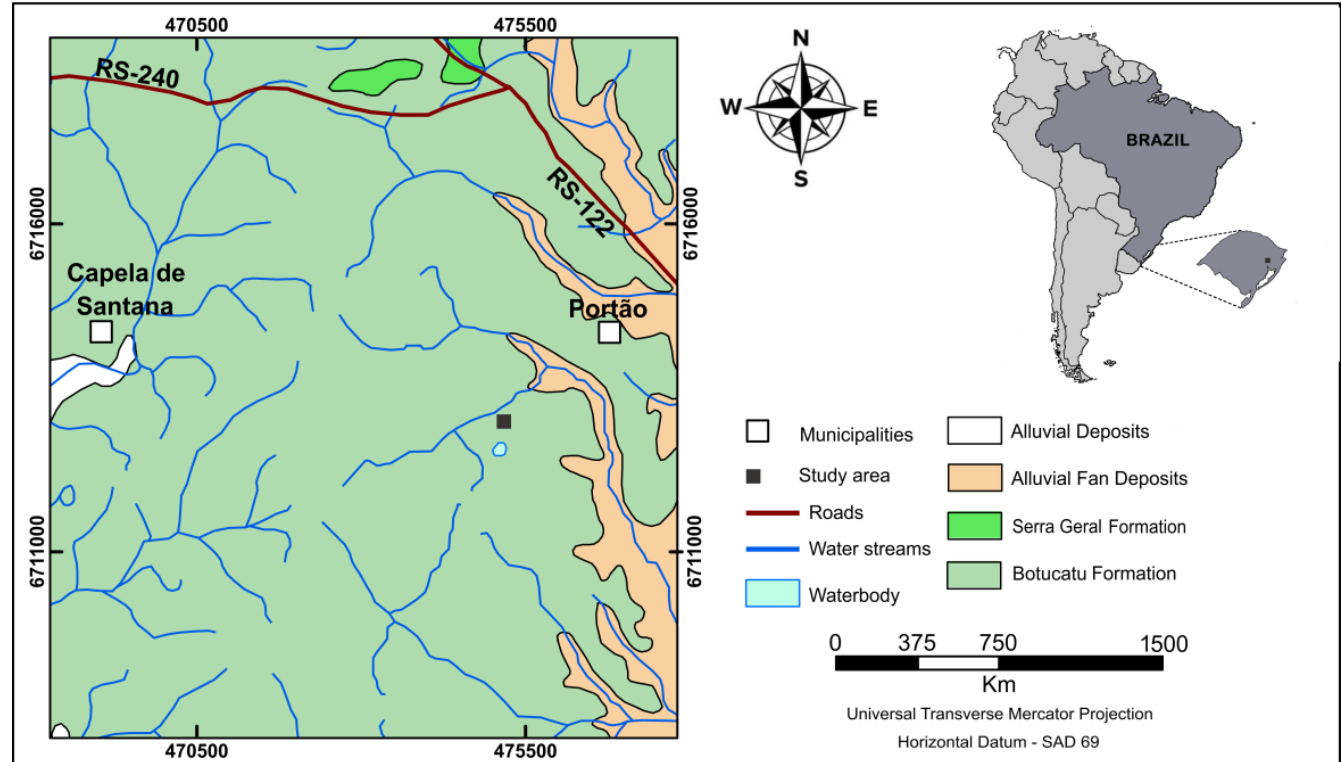

Figure 1 - Location/Geological map of the study area. Modified from CPRM (2006).

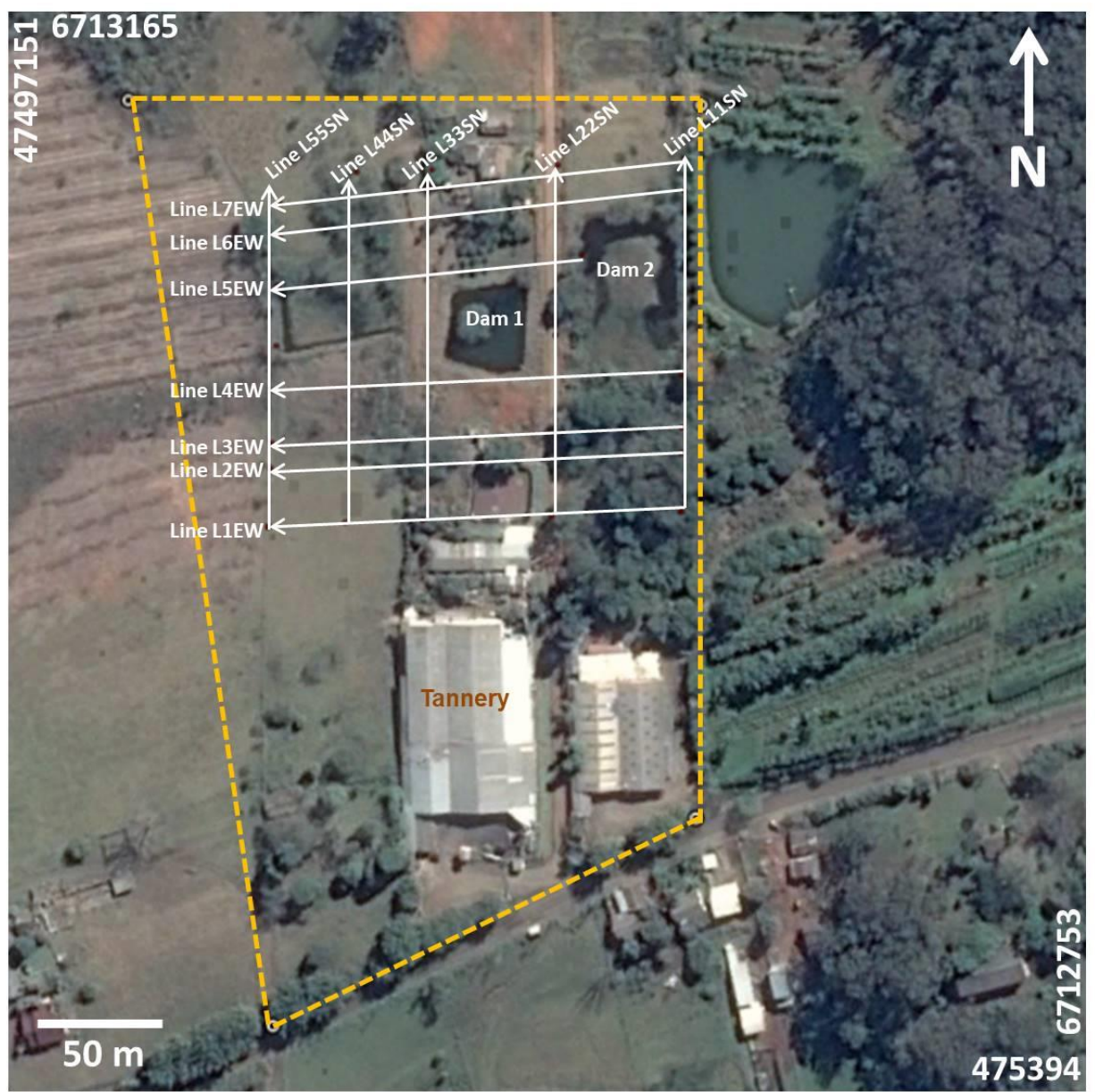

Figure 2 - Map of the study area, indicating the survey lines of geophysical methods (electrical resistivity and induced polarization). Google Earth (2015). 


\section{Results and Discussion}

Survey lines near the tannery are the most representative, displaying geophysical contrasts (Figures 3 and 4). The figure 3 displays the RES and IP 2D depth models by inversion of the lines EW 1,2 and 3. The upper profile at the figure $3 A$ represents the $L 1 E W$ resistivity while the other profile at the bottom represents the chargeability. According to the resistivity profile, the interval from 60 to $90 \mathrm{~m}$ is correlated with the contaminant plume, coinciding with the low IP values and the location of industrial effluent pond. At this model, there is low resistivity values extending downward, however, the values that characterizes the contaminant plume are $<60$ Ohm.m for resistivity and $<3 \mathrm{mV} / \mathrm{V}$ for chargeability, limiting the depth of probable contaminant plume to 7 meters. Figure $3 \mathrm{~B}$ as the $3 \mathrm{~A}$ and $3 \mathrm{C}$ shows the resistivity $2 \mathrm{D}$ depth models above the chargeability model. At the L2EW profile there are resistivity values below $49 \mathrm{Ohm} . \mathrm{m}$ at the horizontal interval from 55 to $95 \mathrm{~m}$ with maximum depth of $5 \mathrm{~m}$. The chargeability below $3 \mathrm{mV} / \mathrm{V}$ is placed from 20 to $80 \mathrm{~m}$. Figure $3 \mathrm{C}$ represents the L3EW model, and its initial point is correlated with the position $20 \mathrm{~m}$ of L1EW and L2EW, with total length of $140 \mathrm{~m}$. The models allow identifying 3 layers: shallower layer (vadose zone, unconfined aquifer), middle layer (confining unit) and the deep layer (confined aquifer). The line 33 SN (figure 4) models, perpendicular to the previous one (figure 2), exhibit clearly the low resistivity and chargeability spatial distribution, suggesting the flow direction. Isoresistivity and isochargeability maps until level 7 were elaborated, with maximum depth of $37 \mathrm{~m}$. However, only the maps that allow characterizing the contaminant plume aredisplayed, as after the level 4 (12 $\mathrm{m}$ deep) the anomalies do not reflect the contamination. The low resistivity values present deeper than $7 \mathrm{~m}$ are related to the confined aquifer, that has no influence from the vadose zone and the unconfined aquifer. Then, the figure 5 illustrate the maps of isoresistivity and isochargeability of all survey lines (EW and SN), at the following depths: $\mathrm{n} 1$ = surface, $\mathrm{n} 2=3 \mathrm{~m}$ and $\mathrm{n} 3=7 \mathrm{~m}$. The figure $5 \mathrm{~A}$ exhibit the resistivity values at the surface, partially matching the chargeability anomalies (figure $5 \mathrm{~B}$ ). Figure $5 \mathrm{~A}$ clearly show the contamination plume limited by the $60 \mathrm{Ohm} . \mathrm{m}$ isoline, suggesting that the flow direction matches the terrain topography. As occurs at the superficial level, at the level 2 (Figure 5C and D) the resistivity values distribution keeps the same pattern, limiting the plume to the area surrounded by values higher than $60 \mathrm{Ohm} . \mathrm{m}$, apparently limited by the 22SN and 44SN survey lines (figure 5C). The chargeability pattern is similar (Comparing the figures $5 \mathrm{~B}$ and $5 \mathrm{D}$ ). The maps displayed at figures $5 \mathrm{E}$ and $5 \mathrm{~F}$, show the resistivity and chargeability values, respectively, at the level 3 that is $7 \mathrm{~m}$ deep.
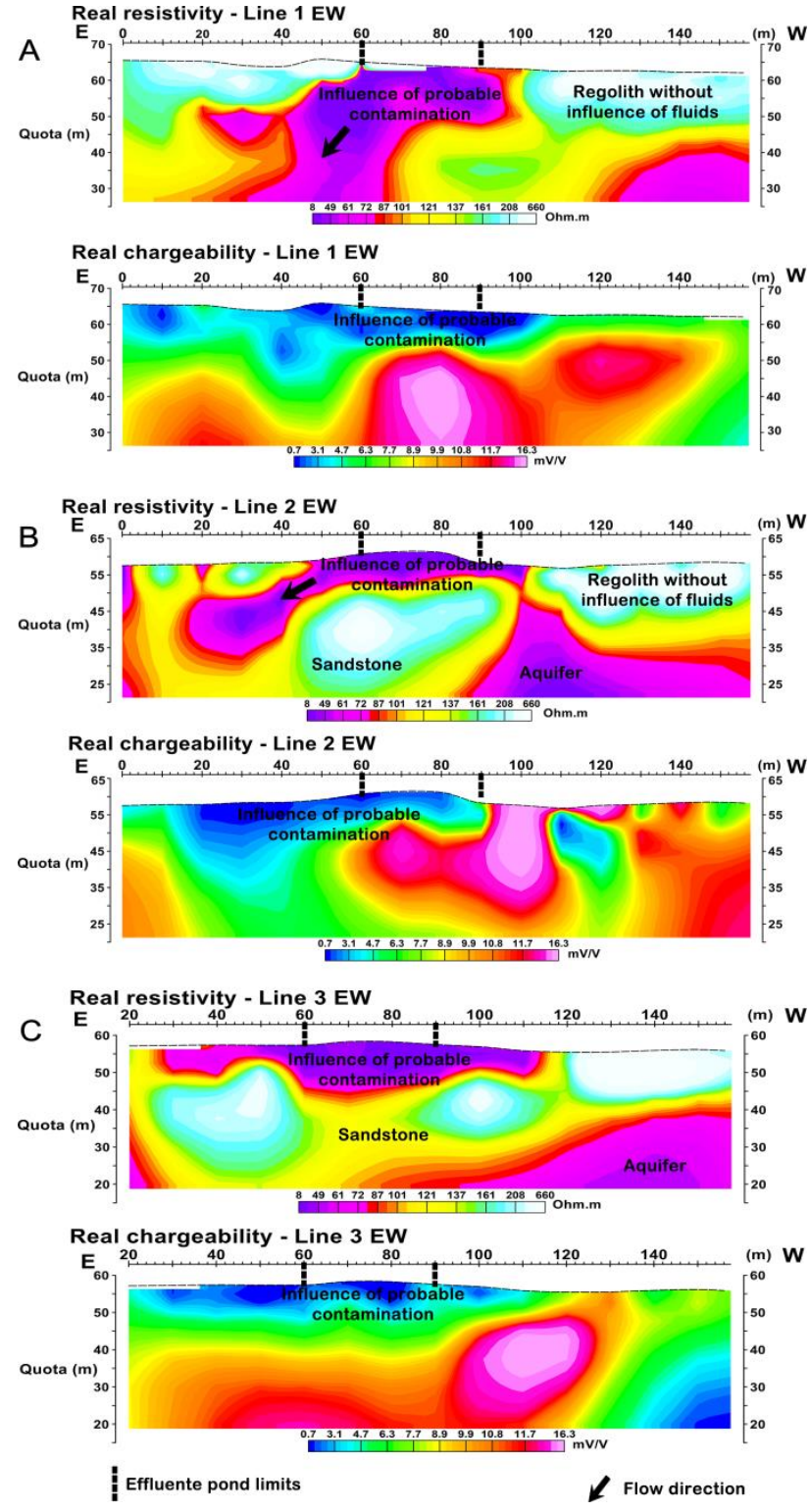

Figure 3 - Resistivity and chargeability 2D depth models of the Lines $1 E W(A), 2 E W(B)$ and $3 E W(C)$ (see location in Figura 2).

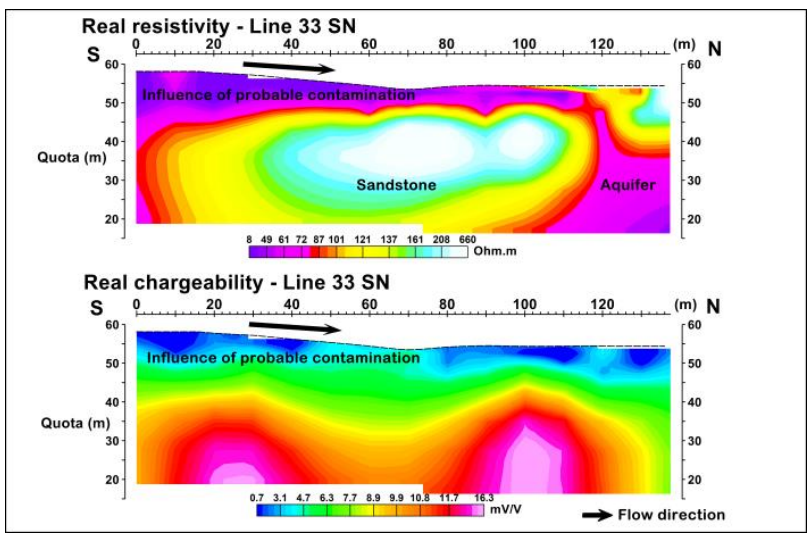

Figure 4 - Resistivity and chargeability $2 D$ depth models of the Line 33 SN (see location in Fig. 2) 

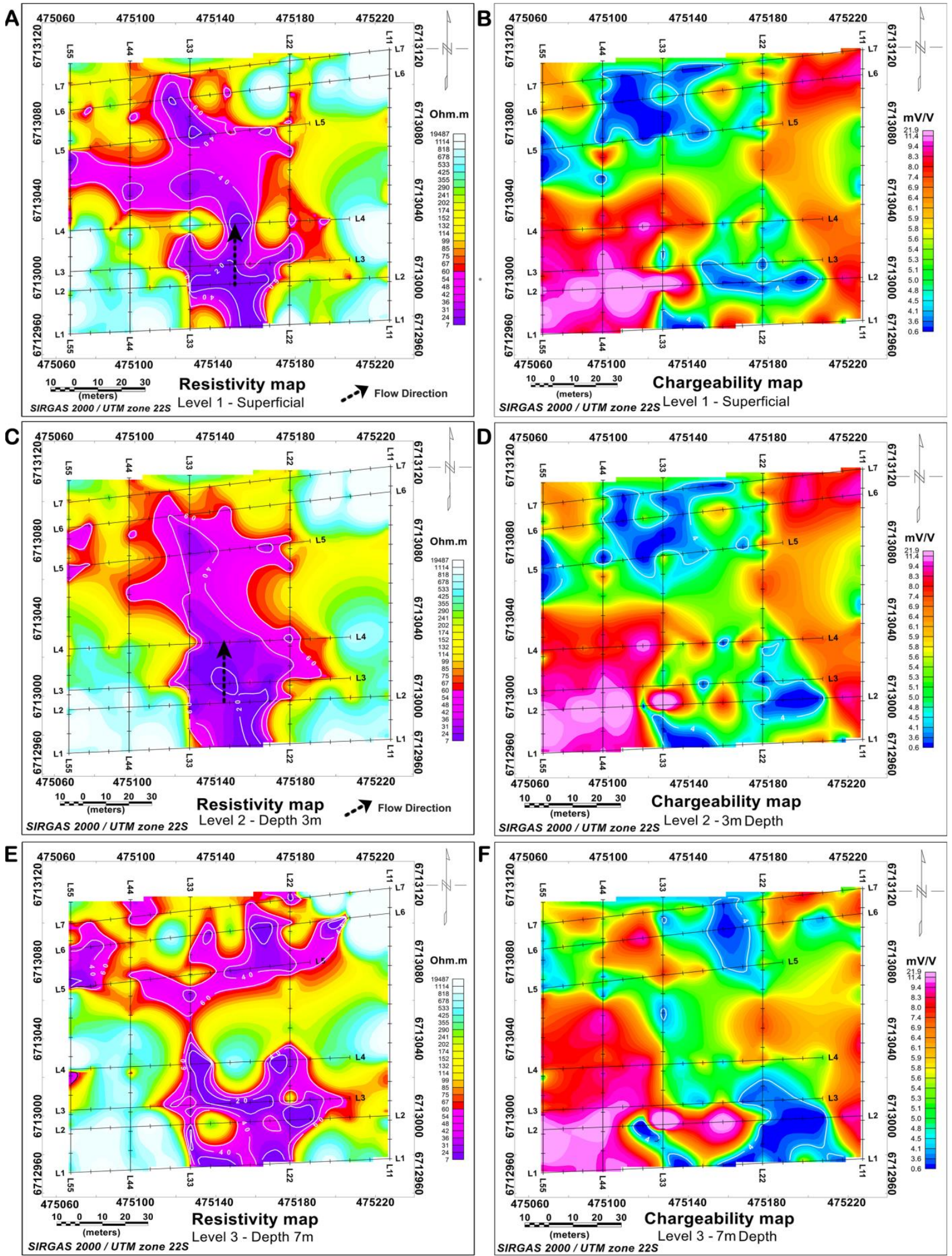

Figure 5 - Resistivity $(A, C, E$ - superficial, depth $3 \mathrm{~m}$ and depth $7 m$, respectively) and chargeability maps $(B, D, F$ superficial, depth $3 \mathrm{~m}$ and depth $7 \mathrm{~m}$, respectively). 


\section{Conclusions}

Electrical resistivity and induced polarization applied using dipole-dipole array $(A B=M N=10 m)$, were efficient to outline the plume boundary horizontally and vertically. Electrical resistivity was the most effective technique. The geophysical results allow us to characterize the plume by its low resistivity values $(<60$ ohm.m), that mainly corresponds with low chargeability values $(<3 \mathrm{mV} / \mathrm{V})$. Contrasting with higher values $(>60$ Ohm.m and $>3$ $\mathrm{mV} / \mathrm{V}$ ) of the no contaminated residual soil and sandstone. Concerning the geoelectric methods resolution, until the depth of $7 \mathrm{~m}$, the plume can be better outlined. The depth models allowed to estimate the lateral $(50 \times 60 \mathrm{~m})$ and vertical $(7 \mathrm{~m})$ dimensions of the contaminant plume, determining its preferential flow direction to the north, matching the terrain topography. The results suggest that the contaminated area is restrict to the source surrounding. The use of more than one geophysical method in environmental studies permits to generate reliable data for contaminant remediation and management.

\section{Acknowledgments}

The authors thanks to the Federal University of Paraná for borrowing the equipment to acquire electromagnetics data. A.M.P. Lau thanks the Programa de Aperfeiçoamento de Pessoal de Nível Superior (CAPES) for the scholarship. F.J.F. Ferreira and E.F. da Rosa Filho were supported in this research by Conselho Nacional de Desenvolvimento Científico e Tecnológico (CNPq) under contracts 306978/2015-6 and 301833/2014-1, respectively.

\section{References}

CPRM - Companhia de Pesquisa de Recursos Minerais. 2005. Mapa Hidrogeológico do Estado do Rio Grande Sul. Porto Alegre, RS. 1 CD-ROM. Escala 1:750.000. In portuguese.

CPRM - Companhia de Pesquisa de Recursos Minerais. 2006. Projeto Plano Diretor de Mineração da Região Metropolitana de Porto Alegre - PDM, Escala: 1:250.000 - Superintendêndencia Regional de Porto Alegre - RS, Brasil. In portuguese.

Cunha I. F. J. \& Shiraiwa S. 2011. Aplicação do método eletromagnético indutivo na investigação da pluma de contaminação da água subterrânea por resíduos de cromo de curtume. Revista Brasileira de Geofísica. Rio de Janeiro, 29 (1): 127-134 p.

Fachin, S. J. da S., Huber F., Shiraiwa S., Borges W. R., Migliorini R. B. 2006. Aplicação De Métodos Geofísicos Para Identificar Áreas Contaminadas Por Resíduos De Um Curtume. Revista Brasileira de Geofísica, Rio de Janeiro, 24 (1): 129-138 p.

Google Earth. 2015. Version 7.1.5.1557. Europa Technologies - US Dept. of State Geographer.

Kearey P., Brooks M., Hill I. 2002. An Introduction to Geophysical Exploration; 3 ed. United Kingdom: Blackwell Publishing Company, p. 262.
Migliorini R. B., Dores E. F. G. C., Silva E. C. 2006. Estudo da disposição final de resíduos sólidos de curtume como fonte de alteração da qualidade das águas subterrâneas. Águas Subterrâneas, São Paulo, 20 (2): 83-96 $\mathrm{p}$.

Milsom J. 2003. Field Geophysics. John Wiley \& Sons Ltda. (3), The Atrium, Southern Gate, Chichester, p. 1249.

Nunes L. P. M. \& Luiz J. G. 2006. Caracterização geoeletrica de área de curtume localizada no distrito industrial de Icoaraci, Bélem-Pará. Revista Brasileira de Geofísica, Rio de Janeiro, 24 (4): 467-481 p.

Reynolds J. M. 2003. An Introduction to applied and environmental geophysics. Jonhn Wiley \& Sons Ltda., New York, USA, 796p.

Telford W. M., Geldart L. P., Sheriff R. E. 1990. Applied Geophysics. 2 ed. New York: Cambridge University Press, 774p. 